\title{
Unveiling the Effect of Garlic and Black Cumin Oil on Egg Yolk Lipid Profile of Birds: A Comparative Study
}

\author{
Shraddha Shrivastava, Aditya Mishra, Amir Amin Sheikh" and B.S. Gehlaut \\ Department of Veterinary Physiology and Biochemistry, College of Veterinary Science and Animal Husbandry, \\ Nanaji Deshmukh Veterinary Science University, Jabalpur, M.P. INDIA \\ "Corresponding author: A A Sheikh; E-mail: amirsheikh3468@gmail.com
}

Received: 22 April, 2021

Revised: 15 May, 2021

Accepted: 19 May, 2021

\begin{abstract}
The present study was aimed to assess the effect of garlic (Allium sativum) and black cumin (Nigella sativa) oil on egg yolk lipid profile of adult layer birds. Forty eight 40 -weeks-old birds were randomly divided into two preparation trials of 24 birds each. Each trial was further divided into 4 groups of 6 birds each. Birds were caged individually and diets were supplemented with 0 (control), 250, 500 and $750 \mathrm{mg}$ garlic and black cumin oil/kg of feed in groups $\mathrm{T}_{1}, \mathrm{~T}_{2}, \mathrm{~T}_{3}$ and $\mathrm{T}_{4}$ respectively for 56 days. The birds of $\mathrm{T}_{4}$ group showed maximum reduction in egg yolk lipid profile on day 56. The present study revealed that Allium sativum oil@750mg $/ \mathrm{kg}$ of feed is the most effective supplementation in reducing the egg lipid profile in birds.
\end{abstract}

\section{HIGHLIGHTS}

(0 Effect of garlic (Allium sativum) and black cumin (Nigella sativa) oil on egg yolk lipid profile of adult layer birds.

(0 Supplementation of Allium sativum oil @ $750 \mathrm{mg} / \mathrm{kg}$ of feed was found most effective in reducing the egg lipid profile.

Keywords: Garlic and Black cumin oil, Egg yolk cholesterol, Egg yolk total lipids, Egg yolk triglycerides, Jabalpur color birds

Natural medicinal products derived from herbs and spices that are used to improve performance in animal and poultry nutrition have been called "phytogenic feed additives" (Windisch et al., 2008). In addition to traditional antibiologies, probiotics and prebiotics, the use of phytogenic foods or herbal plants has recently been given much greater attention. These plants are considered to be natural products and can therefore be voluntarily accepted into poultry feed. Extensive studies of plant growth, antimicrobial, antioxidant and anti-inflammatory functions of plant phytogenes have been identified (Gheisar and Kim, 2017). Furthermore, they stimulate the digestive system by increasing the production of digestive enzymes and improving feed utilization efficiency by enhancing liver functions (Abou-Elkhair et al., 2014). Plant-based feed additives have recently received a lot of attention as alternatives to traditional antibacterial feed additives (Choudhary et al., 2014; Singh and Kumar, 2018). Antibacterial, antifungal, antiparasitic, antioxidant, antimicrobial, and other pharmacological activities are possessed by black cumin (Ahmad, 2013). Since antiquity, many cultures have used garlic (Allium sativum) as both a food and a medicine. Garlic has hypocholesterolemic and antioxidant properties (Jang et al., 2018) due to the presence of compounds such as allin, allicin, ajoene, S-allyl cysteinediallyl sulfide, and diallyltrisulfide (Amagase et al., 2001). Kansal et al. (2017) declared a positive effect on broilers' biochemical parameters in a mixed diet to be 0.75 per cent garlic. Nigella sativa commonly known as Kalonji, has been reported to have hypolipidemic effects (Zaoui et al., 2000). Solvent extracted fixed oil of black cumin has $42.76 \%$ linoleic acid, $16.59 \%$ oleic acid, $8.51 \%$ palmitic acid, $4.71 \%$ eicosatrienoic acid, $5.98 \%$

How to cite this article: Shrivastava, S., Mishra, A., Sheikh, A.A. and Gehlaut, B.S. (2021). Unveiling the effect of garlic and black cumin oil on egg yolk lipid profile of birds: a comparative study. J. Anim. Res., 11(3) 477-481.

Source of Support: None; Conflict of Interest: None 
eicosapentaenoic acid (EPA) and 2.97\% decosahexaenoic acid (DHA) (Kaskoos, 2011). The Nigella sativa seeds have also been reported to reduce serum and yolk total cholesterol, LDL-cholesterol, triglycerides content and increased HDL-cholesterol (Akhtar et al., 2003). In view of above, the present study was undertaken to compare the hypolipidemic effect of garlic and black cumin oil supplementation in Jabalpur color birds.

\section{MATERIAL AND METHODS}

The study was conducted on 48 healthy Jabalpur color birds (pure line developed by the inter-se mating of $3^{\text {rd }}$ generation among the selected stock of Krishna J. Commercial Broiler/Breeder and one color line from Poultry Breeding Farm, Adhartal, Jabalpur) of 40 weeks age. Birds were procured from All India Coordinated Research Project (AICRP) on Poultry Breeding, Adhartal, Jabalpur, MP, India. They were kept separately in individual cages and maintained under similar hygienic conditions at Poultry Farm Adhartal, Jabalpur. The birds were randomly divided into 8 groups having 6 birds each. These groups were fed with diets supplemented with garlic and black cumin oil @ 0, 250, 500 and $750 \mathrm{mg} \mathrm{kg}^{-1}$. The basal diet consisted of $2700 \mathrm{Kcal} \mathrm{ME} \mathrm{kg}^{-1}$ and $17 \%$ protein. Six eggs were collected from each group on $0^{\text {th }}, 14^{\text {th }}, 28^{\text {th }}, 42^{\text {th }}$ and $56^{\text {th }}$ days of feeding. Egg-yolk total lipids were extracted as per Folch et al. (1957) and estimated as per Frings et al. (1972). The egg yolk cholesterol and triglycerides were estimated by standard diagnostic kits (Erba).

\section{STASTISTICAL ANALYSIS}

The data obtained was analyzed using hierarchical analysis of variance (Steel and Torrie, 1992). Comparisons among the treatment means were made by Duncan's (Duncan, 1955) multiple range test.

\section{RESULTS AND DISCUSSION}

The variations in egg-yolk total lipids and cholesterol between groups and between intervals within treatments were highly significant $(\mathrm{P}<0.01)$ whereas those between treatments within groups were significant $(\mathrm{P}<0.05)$ except for egg-yolk triglycerides. The reduction in egg yolk total lipids was $22.96 \%$ in birds fed with $250 \mathrm{mg}$ garlic oil $\mathrm{kg}^{-1}$ diet on $56^{\text {th }}$ day of experiment whereas it was 31.15 and $42.12 \%$ in birds fed with 500 and $750 \mathrm{mg}$ garlic oil kg-1 diet, respectively and $16.04 \%$ in group $\mathrm{T}_{2}, 20.23 \%$ in group $\mathrm{T}_{3}$ and $31.22 \%$ in group $\mathrm{T}_{4}$ of black cumin oil on day 56 of the experiment (Table 1). No significant change was observed in control. Similar pattern of reduction in egg-yolk total lipids has been reported by Hebbar (2010) on dietary supplementations consisting of five plants, A. sativum, Cuminum cyminum, Terminalia arjuna, cinnamon and Tinospora cordifolia in the ratio of 3:2:2:2:1@ $4500 \mathrm{mg}$ $\mathrm{kg}^{-1}$ feed in adult layer birds. Similar pattern of reduction $(14 \%)$ in egg yolk total lipids was reported by Bagir et al. (2006) on dietary supplementations of black cumin seed of feed in adult White Leghorn birds.

The egg-yolk cholesterol was reduced by $22.75,29.60$ and $35.61 \%$ in birds fed with 250,500 and $750 \mathrm{mg}$ garlic oil kg-1 diet, respectively and 11.97 in group $\mathrm{T}_{2}, 21.73$ in group $\mathrm{T}_{3}$ and 27.36 in group $\mathrm{T}_{4}$ in the black cumin oil fed group on day 56 of the experiment (Table 2). Chowdhury et al. (2002) observed 5-24\% reduction in yolk cholesterol of laying hens when fed on diets supplemented with garlic

Table 1: Egg yolk total lipids ( $\left.\mathrm{mg} \mathrm{g}^{-1}\right)$ in Jabalpur color birds fed with diets supplemented with garlic and black cumin oils (mean \pm $\mathrm{SE} ; \mathrm{n}=6$ )

\begin{tabular}{|c|c|c|c|c|c|c|}
\hline Groups & Treatments & Day 0 & Day 14 & Day 28 & Day 42 & Day 56 \\
\hline \multirow{4}{*}{ Garlic oil } & $\mathrm{T}_{1}$ & $314.29 \pm 5.47$ & $314.89 \pm 1.02$ & $311.63 \pm 2.30$ & $313.76 \pm 1.97$ & $313.49 \pm 3.29$ \\
\hline & $\mathrm{T}_{2}$ & $315.11^{\mathrm{a}} \pm 2.23$ & $308.83^{\mathrm{a}} \pm 2.61$ & $295.64^{b} \pm 3.66$ & $274.07^{\mathrm{c}} \pm 3.41$ & $242.76^{\mathrm{d}} \pm 1.35$ \\
\hline & $\mathrm{T}_{3}$ & $317.05^{\mathrm{a}} \pm 3.38$ & $306.77^{b} \pm 1.94$ & $285.06^{c} \pm 3.96$ & $261.94^{\mathrm{d}} \pm 2.14$ & $218.28^{\mathrm{e}} \pm 2.08$ \\
\hline & $\mathrm{T}_{4}^{3}$ & $312.82^{\mathrm{a}} \pm 1.79$ & $299.19^{b} \pm 2.91$ & $265.55^{\mathrm{c}} \pm 3.05$ & $232.16^{\mathrm{d}} \pm 1.84$ & $181.06^{\mathrm{e}} \pm 4.85$ \\
\hline \multirow{4}{*}{ Black cumin oil } & $\mathrm{T}_{1}^{4}$ & $347.08 \pm 2.69$ & $345.26 \pm 1.55$ & $344.17 \pm 1.23$ & $344.71 \pm 0.86$ & $343.44 \pm 3.09$ \\
\hline & $\mathrm{T}_{2}$ & $317.64^{\mathrm{a}} \pm 1.11$ & $306.57^{\mathrm{b}} \pm 1.79$ & $290.29^{c} \pm 0.79$ & $273.77^{\mathrm{d}} \pm 1.22$ & $266.68^{d} \pm 0.91$ \\
\hline & $\mathrm{T}_{3}$ & $316.21^{\mathrm{a}} \pm 1.95$ & $303.99^{\mathrm{b}} \pm 2.48$ & $286.97^{c} \pm 2.74$ & $273.89^{d} \pm 3.81$ & $252.56^{\mathrm{e}} \pm 2.59$ \\
\hline & $\mathrm{T}_{4}$ & $315.55^{\mathrm{a}} \pm 2.72$ & $292.28^{\mathrm{b}} \pm 2.37$ & $267.88^{\mathrm{c}} \pm 2.62$ & $226.38^{\mathrm{d}} \pm 3.39$ & $217.02^{\mathrm{e}} \pm 1.83$ \\
\hline
\end{tabular}

Mean values with different superscripts in a row vary significantly $(p<0.01)$. 
Table 2: Egg yolk cholesterol $\left(\mathrm{mg} \mathrm{g}^{-1}\right)$ in Jabalpur color birds fed with diets supplemented with garlic and black cumin oils (mean \pm $\mathrm{SE} ; \mathrm{n}=6$ )

\begin{tabular}{lllllll}
\hline Groups & Treatments & Day 0 & Day 14 & Day 28 & Day 42 & Day 56 \\
\hline \multirow{4}{*}{ Garlic oil } & $\mathrm{T}_{1}$ & $17.47 \pm 0.19$ & $17.98 \pm 0.39$ & $17.72 \pm 0.23$ & $17.68 \pm 0.29$ & $17.95 \pm 0.20$ \\
& $\mathrm{~T}_{2}$ & $17.40^{\mathrm{a}} \pm 0.14$ & $16.32^{\mathrm{b}} \pm 0.17$ & $15.61^{\mathrm{b}} \pm 0.13$ & $14.71^{\mathrm{c}} \pm 0.21$ & $13.44^{\mathrm{d}} \pm 0.13$ \\
& $\mathrm{~T}_{3}$ & $17.33^{\mathrm{a}} \pm 0.19$ & $16.93^{\mathrm{a}} \pm 0.24$ & $15.36^{\mathrm{b}} \pm 0.21$ & $14.33^{\mathrm{c}} \pm 0.19$ & $12.20^{\mathrm{d}} \pm 0.32$ \\
& $\mathrm{~T}_{4}$ & $17.41^{\mathrm{a}} \pm 0.15$ & $16.86^{\mathrm{a}} \pm 0.12$ & $15.22^{\mathrm{b}} \pm 0.18$ & $13.96^{\mathrm{c}} \pm 0.28$ & $11.21^{\mathrm{d}} \pm 0.09$ \\
\hline \multirow{3}{*}{ Black cumil } & $\mathrm{T}_{1}$ & $18.43^{ \pm} \pm 0.19$ & $18.48 \pm 0.31$ & $18.31 \pm 0.19$ & $18.31 \pm 0.12$ & $18.11 \pm 0.23$ \\
oil & $\mathrm{T}_{2}$ & $17.71^{\mathrm{a}} \pm 0.15$ & $17.65^{\mathrm{a}} \pm 0.11$ & $17.03^{\mathrm{ab}} \pm 0.12$ & $16.52^{\mathrm{b}} \pm 0.11$ & $15.59^{\mathrm{c}} \pm 0.06$ \\
& $\mathrm{~T}_{3}$ & $17.44^{\mathrm{a}} \pm 0.13$ & $16.64^{\mathrm{b}} \pm 0.12$ & $15.76^{\mathrm{c}} \pm 0.22$ & $15.13^{\mathrm{c}} \pm 0.27$ & $13.65^{\mathrm{d}} \pm 0.14$ \\
& $\mathrm{~T}_{4}$ & $17.62^{\mathrm{a}} \pm 0.27$ & $17.29^{\mathrm{a}} \pm 0.26$ & $16.11^{\mathrm{b}} \pm 0.19$ & $15.09^{\mathrm{c}} \pm 0.25$ & $12.80^{\mathrm{d}} \pm 0.21$ \\
\hline
\end{tabular}

Mean values with different superscripts in a row vary significantly $(\mathrm{p}<0.01)$.

Table 3: Egg yolk triglyceride ( $\left.\mathrm{mg} \mathrm{g}^{-1}\right)$ in Jabalpur color birds fed with diets supplemented with garlic and black cumin oils (mean \pm $\mathrm{SE} ; \mathrm{n}=6$ )

\begin{tabular}{|c|c|c|c|c|c|c|}
\hline Groups & Treatments & Day 0 & Day 14 & Day 28 & Day 42 & Day 56 \\
\hline \multirow{4}{*}{ Garlic oil } & $\mathrm{T}_{1}$ & $181.09^{\mathrm{b}} \pm 1.14$ & $180.36^{\mathrm{b}} \pm 0.72$ & $181.58^{\mathrm{b}} \pm 1.44$ & $183.27^{\mathrm{a}} \pm 1.69$ & $180.91^{b} \pm 1.429$ \\
\hline & $\mathrm{T}_{2}$ & $184.51^{\mathrm{a}} \pm 0.89$ & $178.45^{\mathrm{b}} \pm 1.57$ & $168.98^{\mathrm{c}} \pm 1.64$ & $158.84^{\mathrm{d}} \pm 1.77$ & $153.59^{\mathrm{e}} \pm 1.28$ \\
\hline & $\mathrm{T}_{3}$ & $185.73^{\mathrm{a}} \pm 0.64$ & $180.77^{\mathrm{b}} \pm 1.74$ & $171.39^{\mathrm{c}} \pm 1.75$ & $162.15^{\mathrm{d}_{ \pm}} \pm 0.62$ & $152.40^{e^{e}} \pm 0.96$ \\
\hline & $\mathrm{T}_{4}$ & $186.80^{\mathrm{a}} \pm 0.61$ & $176.46^{\mathrm{b}} \pm 1.21$ & $165.56^{\mathrm{c}} \pm 0.75$ & $155.46^{\mathrm{d}} \pm 1.31$ & $145.46^{\mathrm{e}} \pm 0.881$ \\
\hline \multirow{4}{*}{$\begin{array}{l}\text { Black } \\
\text { cumin oil }\end{array}$} & $\mathrm{T}_{1}$ & $182.63^{\mathrm{b}} \pm 1.33$ & $182.81^{\mathrm{b}} \pm 3.60$ & $184.55^{\mathrm{a}} \pm 4.19$ & $181.66^{\mathrm{b}} \pm 4.16$ & $182.38^{\mathrm{b}} \pm 2.048$ \\
\hline & $\mathrm{T}_{2}$ & $185.96^{\mathrm{a}} \pm 0.94$ & $181.20^{\mathrm{b}} \pm 0.92$ & $176.71^{c} \pm 1.15$ & $171.09^{\mathrm{d}} \pm 1.34$ & $165.96^{\mathrm{e}_{ \pm}}+1.792$ \\
\hline & $\mathrm{T}_{3}^{2}$ & $181.01^{\mathrm{a}} \pm 1.06$ & $176.83^{\mathrm{b}} \pm 1.15$ & $171.79^{c} \pm 1.46$ & $161.41^{\mathrm{d}_{ \pm}} 1.48$ & $152.07^{\mathrm{e}} \pm 0.704$ \\
\hline & $\mathrm{T}_{4}$ & $185.94^{\mathrm{a}} \pm 1.13$ & $179.48^{\mathrm{b}} \pm 2.19$ & $170.34^{c} \pm 2.79$ & $160.63^{\mathrm{d}} \pm 1.95$ & $149.76^{\mathrm{e}} \pm 0.983$ \\
\hline
\end{tabular}

Mean values with different superscripts in a row vary significantly $(p<0.01)$.

paste. Khan et al. (2008) observed a significant reduction in egg yolk cholesterol concentration with increasing level of oven-dried garlic powder from 0 to $8 \%$ in native desilayers for 6 weeks. Yalcin et al. (2009) reported significant reduction $(p<0.01)$ in egg yolk cholesterol levels in Lohmann Brown laying hens 36 weeks of age after administration of black cumin seed. Significant $(p<0.05)$ decrease in egg cholesterol was also reported by Akhtar et al. (2003) and Aydin et al. (2008).

Like egg-yolk total lipids and cholesterol, triglyceride values were reduced in birds fed with all the preparations in all the treatments in a dose-dependent manner (Table 3). The reduction was $16.76,17.94$ and $22.13 \%$ in birds fed with 250,500 and $750 \mathrm{mg}$ garlic oil $\mathrm{kg}^{-1}$ diet, respectively, whereas the reduction was $10.75,15.99$ and $19.46 \%$ in black cumin oil fed group respectively on day 56 of the experiment. Hebbar (2010) reported 19.19\% reduction in egg yolk triglyceride values on supplementing the diet by a polyherbal preparation. Bagir et al. (2006) observed reduction of $21 \%$ and $23 \%$ in egg yolk triglycerides in White Leghorns on supplementation of black cumin.

\section{CONCLUSION}

The study revealed that garlic and black cumin oil supplementation@ 750 mg kg-1 diet significantly reduced egg yolk lipid level in birds on $56^{\text {th }}$ day of feeding, but on comparison between these two, garlic oil shows better results than the black cumin oil. Garlic oil can be effectively used for reducing total lipids, cholesterol and triglyceride contents in egg-yolk of poultry birds and these eggs can be consumed safely without the risk of cardiovascular diseases. We can also conclude that both the oils can be used in prevention of cardiovascular diseases.

\section{REFERENCES}

Abou-Elkhair, R., Ahmed, H.A. and Selim, S. 2014. Effects of black pepper (Piper nigrum), turmeric powder (Curcuma 
longa) and coriander seeds (Coriandrum sativum) and their combinations as feed additives on growth performance, carcass traits, some blood parameters and humoral immune response of broiler chickens. Asian-Australas J. Anim. Sci., 27: 847-854.

Ahmad, A., Husain, A., Mujeeb, M., Khan, S.A., Najmi, A.K., Siddique, N.A., Damanhouri, Z.A, and Anwar, F. 2013. A review on therapeutic potential of Nigella sativa: A miracle herb. Asian Pac. J. Trop. Biomed., 3: 337-352.

Akhtar, M. S., Zahid, N., and Abid, A. R. 2003. Effect of feeding powdered Nigella sativa L. seeds on poultry egg production and their suitability for human consumption. Vet. Arch., 73: 181-190.

Al-Hader, A., Aqel, M., and Hasan, Z. 1993. Hypoglycemic effects of the volatile oil of Nigella sativa. Int. J. Pharmacog., 31: 96-100.

Amagase, H., Petesch, B.L., Matsuura, H., Kasuga, S. and Itakura, Y. 2001. Intake of garlic and its bioactive components. J. Nutr., 131: 955S-962S.

Aydin, R., Karaman, M., Ciek, T., and Yardibi, H. 2008. Black cumin (Nigella sativa L.) supplementation into the diets of laying hen positively influences egg yield parameters, shell quality and decreases egg cholesterol. Poult. Sci., 87: 25902595.

Bagir NME, Hama AY, Hamed RM, Rahim AG and Beynen, AC. 2006. Lipid composition of egg yolk and serum in laying hens fed diets containing black cumin (Nigella sativa). Int. J. Poult. Sci., 5(6): 574-578.

Canogullari, S., Baylan, M., Erdogan, Z., Duzguner, V., and Kucukgul, A. 2009. The effects of dietary garlic powder on performance, egg yolk and serum cholesterol concentration in laying quails. Czech. J. Anim. Sci., 55: 286-293.

Chi, MS., Koh, E.T. and Steward, T.J. 1982. Effects of garlic on lipid metabolism in rats fed cholesterol or lard. J. Nutr., 112: 241-248.

Choudhary, R.K., Singh, V.K., Singh, S.P., Sahoo, B. and Singh, A.K. 2014. Comparative efficacy of turmeric (Curcuma longa), amla (Emblica officinalis) and mangrail (Nigella sativa) as growth promoters in broilers. Anim. Nut. Feed Technol., 14: 273-281.

Chowdhury, M.M.R., Moinuddin, S.M. and Islam, M.K. 2008. Effects of turmeric and garlic on blood cholesterol level in guinea pig. Bangla. J. Pharmacol., 3: 17-20.

Chowdhury, S.R., Chowdhury, S.D. and Smith, T.K. 2002. Effect of dietary garlic on cholesterol metabolism in laying hens. Poult. Sci., 81: 1862.

Duncan, D.B. 1955. Multiple range and multiple F tests. Biomet, 11: $1-42$.
El-Kamali, H.H., Ahmed, A.H. and Mohammed, A.A.M. 1998. Antibacterial properties of essential oils from Nigella sativa seeds, Cymbopogon citratus leaves and Pulicaria undulata aerial parts. Fitoter, 69: 77-78.

Erener, G., Altop, A., Ocak, N., Aksoy, H. M., Cankaya, S., and Ozturk, E. 2010. Influence of black cumin seed (Nigella sativa L.) and seed extract on broilers performance and total coliform bacteria count. Asian J. Anim. Vet. Adv., 5: 128-135.

Folch, J., Lees, M. and Sloane-Stanley, G.H. 1957. A simple method for isolation and purification of total lipids from animal tissues. J. Biol. Chem., 226: 497-509.

Frings, C.S., Fendley, T.W., Dunn, R.T. and Queen, C.A. 1972. Improved determination of total serum lipids by sulphophosphovanillin reaction. Clin. Chem., 18: 673-674.

Ghasemi, R., Zarei, M., and Torki, M. 2010. Adding medicinal herbs including garlic (Allium sativum) and thyme (thymus vulgaris) to diet of laying hens and evaluating productive performance and egg quality characteristics. Am. J. Anim. Vet. Sci., 5: 151-154.

Gheisar, M. M. and Kim, I.H. 2017. Phytobiotics in poultry and swine nutrition-a review. Ital. J. Anim. Sci., 17: 92-99.

Hebbar, A.H. 2010. Effect of Polyherbal Dietary Supplementations on Lipid Profile of Jabalpur Colour Layer Birds. M.V.Sc. and A.H. Thesis, JNKVV, Jabalpur, M.P., India.

Jang, H.J., Lee, H.J., Yoon, D.K., Ji, D.S., Kim, J.H. and Lee, C.H. 2018. Antioxidant and antimicrobial activities of fresh garlic and aged garlic by-products extracted with different solvents. Food Sci. Biotechnol., 27: 219-225.

Kansal, A., Ali, N., Fahim, A., Bharti, M., Chandra G. and Siddiqui, R. 2017. Effect of Dietary Supplementation of Garlic on the Haemato-biochemical Parameters and Performance of Broiler Chickens. Int. J. Livest. Res., 7(10): 223-230.

Kaskoos, R.A. 2011. Fatty acid composition of black cumin oil from Iraq. Res. J. Med. Plant., 5(1): 85-89.

Khan, S.H., Hassan, S., Sardar, R. and Anjum, M.A. 2008. Effects of dietary garlic powder on cholesterol concentration in native desi-laying hens. Am. J. Food Tech., 3: 207-213.

Mahmoud, M.R., El-Abhar, H.S. and Saleh, S. 2002. The effect of Nigella sativa oil against liver damage induced by Shistosoma mansoni infection in mice. J. Ethnopharmacol., 79: $1-11$.

Mouhajir, F., Pedersen, J.A., Rejdali, M. and Towers, G.H. N. 1999. Antimicrobial thymohydroquinones of Moroccan Nigella sativa seeds detected by electron spin resonance. Pharmacol. Biol., 37: 391-395. 
Nair, M.K.M., Vasudevan, P. and Venkitanarayanan, K. 2005. Antibacterial effect of black seed on Listeria monocytogenes. Food Sci., 16: 395-398.

Nasir, Z. and Grashorn, M.A. 2009. Effects of Echinacea purpurea and Nigella sativa supplementation on broiler performance, carcass and meat quality. J. Anim. Feed. Sci., 19: 94-104.

Singh P.K. and Kumar, A. 2018. Effect of dietary black cumin (Nigella sativa) on the growth performance, nutrient utilization, blood biochemical profile and carcass traits in broiler chickens. Anim. Nutr. Technol., 18: 409-419.

Steel, R.G.D. and Torrie, J.H. 1992. Principles and Procedures of Statistics: A Biometrical Approach. McGraw Hill, New York, USA.
Windisch, W., Schedle, K., Plitzner, C. and Kroismayr, A. 2008. Use of phytogenic products as feed additives for swine and poultry. J. Anim. Sci., 86: 140-148.

Yalcin, S.H., Bugdayci, K.E., Ozsoy, B., and Cakir, S. 2009. Effects of dietary black cumin seed (Nigella sativa L.) on performance, egg traits, egg cholesterol content and egg yolk fatty acid composition in laying hens. J. Sci. Food Agri., 89: 1737-1742.

Zahid, N. 2009. Comparison of effects of Echinacea purpurea juices and Nigella sativa seeds on performance, some blood parameters, carcass and meat quality of broilers. Ph.D. Thesis, Universität Hohenheim Stuttgart, Germany.

Zaoui, A. and Cherrah, Y. 2000. Diuretic and hypotensive effects of Nigella sativa on the spontaneously hypertensive rat. Therapie London, 55(3): 379-382. 
